\title{
PERFORMANCE PERSPECTIVES FOR SMALL AND MEDIUM ENTERPRISES IN CAMEROON: INNOVATION AND ICTs *
}

\author{
André Dumas TSAMBOU1, Benjamin FOMBA KAMGA2
}

DOI: 10.1515/tjeb-2017-0005

This paper studies the combined effects of innovation and information and communication technologies (ICT) on the performance of Small and Medium Enterprises (SMEs). To do this, it uses data from the "General survey of Companies in Cameroon", conducted on 93,969 companies by the National Institute of Statistics (NIS). Of the 93,969 companies surveyed, only 8035 enterprises were questioned according to the synthesis report published in 2010 by the NIS. From this sample, this study extracts innovative SMEs and applies a multiple regression model to assess the direct effects of innovative activities and the use of ICT on SME performance. The econometric analysis shows that: ICT helps to increase SME performance by supporting innovation through the acquisition of new software and hardware equipment. Thus, innovation accompanied by the firm's use of ICT has a significant effect on performance since Software and Machinery Acquisition related to technological innovations contribute to the firm's productivity. However, the degree to which the use of ICTs is rooted in the company can accelerate the innovation process and, in the same way, improve firm performance in terms of cost reduction and rationalisation of processes.

Keywords: $\quad$ Innovation, performance, SME, ICT.

JEL Classification: 032, 014, M13, L25

\footnotetext{
* Acknowledgement:

This article has benefited from the technical and financial support of the International Development Research Center (IDRC) within the framework of the project "Analysis of the Determinants of Business Performance in Francophone Africa" and the Eugen lonescu Fellowship Program 2016 / 2017.

Thanks to Professor Nicolae BIBU of the Western University of Timisoara and Professor Ballo Zié at the University of Felix Houphouet Boigny in Abidjan for their support in writing this paper.

${ }^{1}$ Researcher, University of Yaoundé II-Soa, Faculty of Economics and Management, Cameroon.

2 Professor PhD, University of Yaoundé II-Soa, Faculty of Economics and Management, Cameroon
} 


\section{Introduction}

For several years, many studies have converged to stress the importance of small and medium-sized enterprises (SMEs) in the economies of both developed and developing countries. Regarded as an essential component of the market economy, SMEs have indeed played a significant role in innovation, job creation and the economic growth of the industrialised countries during the $20^{\text {th }}$ century (Quiles, 1997). In developing countries and Sub-Saharan Africa (SSA) in particular, SMEs make up the near total of the population of companies: approximately 99\% in Cameroon (INS, 2009), 93\% in Morocco, more than $90 \%$ in the DRC and 95\% of manufacturing activity in Nigeria (OECD, 2005a). In spite of this weight, the contribution of SMEs to GDP is estimated at less than $20 \%$ in the majority of African countries, whereas it reaches up to $60 \%$ in high income countries (Admassu, 2009). Moreover, SMEs which operate in SSA on average employ less than $30 \%$ of labour in the manufacturing sector whereas this proportion is $74 \%$ in the Asian countries, $62 \%$ in the countries of the Latin America and the Caribbean and $73 \%$ in the OECD countries (Ondel'ansek, 2010). In Cameroon, SMEs employ $61 \%$ of the working population and their contribution to the GDP is estimated at 31\% (INS, 2009).

Beyond this contrast, it should be noted that in developing countries like Cameroon, SMEs have an enormous potential as regards job creation, the stimulation of the spirit of entrepreneurship, and the creation of an industrial tissue able to adapt to the needs of the large domestic companies. Also, it is admitted that they could contribute more to the economic growth of Cameroon if they managed to find better combinations of information and communication technologies (ICT) and innovation in order to increase their productivity and ensure a better performance. In a more general manner, the use of ICT as lever of the benefits of the innovativeness of the companies originates from their capacity to accelerate the process of innovation (Pavlou and Sawy, 2006) or their capacity to better identify the emergent needs of the market (Tambe et al., 2012). Many studies are of the opinion that the problems involved in the use of ICT tools in business practices and the separate or joint adoption of the various types of innovation are the first obstacles to the development of SMEs, rather in front of the problems of corruption, deficiency of the infrastructures or excess taxation (Huang and Liu, 2005; Dibrell et al., 2008). In fact, for their proper functioning, SMEs need the right combination between ICT and innovation. However, it appears that since the

DE GRUYTER OPEN
Timisoara Journal of Economics and Business | ISSN: 2286-0991 | www.tjeb.ro Year 2017 | Volume 10 | Issue 1 | Pages: 68-87 
Tsambou, A. D., \& Fomba Kamga, B. (2017).

Performance perspectives for small and medium enterprises in Cameroon: innovation and ICTs

reform ${ }^{1}$ of the telecommunications sector in Cameroon, the implementation of the system of ICTs alone would be insufficient to generate positive effects on the productivity of SMEs.

To these problems are added those related to innovation that can defined according to the Handbook of Oslo (OECD, 2005b) as the implementation of a product (good or service) or of a new or improved process, of a new method of marketing or a new method of organ isation in the practices of the company, the organization of the place of work or external relations. The OECD thus distinguishes four categories of innovation: The first is product innovation which refers to the introduction of a good or a new or improved service on the level of its characteristics or the use to which it is intended. Secondly, we have process innovation which is the implementation of a method of production or new or improved form of distribution. Thirdly, we have commercial innovation which is the implementation of a new method of commercialisation including significant changes in the design or conditioning, arrangement, promotion or pricing of a product. Fourthly, we have organisational innovation which refers to a new form of work organization, a new system of knowledge management, new methods of mobilization of the creativity of workers, as well as new forms of relationships between the company and its environment. Whatever its form, the economists generally agree (Deltour and Lethiais, 2014) on the idea that the innovation is one of the means to increase efficiency and acquire a competitive advantage while meeting the needs of the market and the strategy of company.

Regarding innovation and ICT as a guarantee of productivity and competitiveness, many studies throughout the world hold that innovation and ICT are a significant source of growth and performance of companies. The lack of this type of study in Cameroon calls for this study to fill the gap, by setting as objective, to evaluate the combined effect of the capacity of innovation and ICT on the performance of the SME.

The rest of this work is organized as follows: The first section does a review of the existing literature, the second presents the methodology, the third the results and their analyses and the fourth section presents the discussion.

\section{Literature review}

Innovation occupies a significant place in the success of goods on the market and through this, on the performance ${ }^{2}$ of companies in general. Detailed attention has therefore been

\footnotetext{
${ }^{1}$ Law 98/014, the capacity of the ICT alone does not have significant impact on the performance of the firm and the activity of innovation alone has a nonlinear impact on the performance (Mbassi, 2011).

${ }^{2}$ According to Burgundian (1995), the performance (action, success and results) of the company is the degree of realization of the required goal. Associated the effectiveness and efficiency (Chandler, 1992), the latter contributes to the improvement of the couple value-cost and tends towards the maximization of the clear creation of value (Lorino, 1997). A
}

\section{DE GRUYTER OPEN}


Tsambou, A. D., \& Fomba Kamga, B. (2017).

Performance perspectives for small and medium enterprises in Cameroon: innovation and ICTs

given to innovation in recent years by business economics theorists (Mairesse et al., 2002; Charreaux, 2004; Raymond and St-Pierre, 2010; Şipoş et Ionescu, 2015; Rukevwe, 2015; Boachie, 2015; Ndesaulwa, 2016). Some authors find a positive link between the degree of innovation and company performance (Seersucker et al., 2000; Jansen et al., 2006; Dibrell et al., 2008 ; Hajjem et al., 2015), while others (Tidd \& Driver, 2000; St-Pierre et al., 2003) obtain mitigated results. Faced with the absence of a consensus on the relationship between innovation and performance in the literature, a mastery of Information and Communication Technologies (ICT) in production units remains a major stake to improve this relationship within firms. The use of this instrument in companies is growing and has spread to many tasks: communication, search for information, the marketing of goods and services, group work, business management, prospection, etc. The repercussions of the information (ICT) systems have for long been a subject of debate.

Following the paradox of the productivity ICT stated by Solow (1987), many authors (Mairesse et al., 2002; Greenan \& Mairesse, 2006; Ben Aoun et al, 2010; Liang et al, 2010) study differences in the productivity gains of ICT. They show that ICTs as well as new products and services positively affect the demand for skilled workers and the labour productivity of firms. It should be admitted that the role and specificities of ICTs in the operation of companies is subject to debate, the role of computer science being not obvious for organizations of small size (Deltour \& Lethais, 2014). These types of firms very often develop a "sense of impotence" (is struggling with the use of ICTs) in the face of ICT because the possible systematic difficulties. The link between ICT and the performance of SMEs is sometimes influenced by factors such as: the location of the ICTs concerned, their complexity, their number or the skills of the associated persons. According to Aral and Weill (2007), the ICT assets (equipment and investments) and the capacities in ICT (competences relating to ICT, practice of ICT) combine with innovations and material and human resources to improve the performance of SMEs.

The combination of the behaviour in terms of equipment and use of ICT with the capacities of innovation of companies results in a dual economic structure. The interaction between ICT and the capacity of innovation ${ }^{3}$ on performance has led to contradictory results in previous studies. Some studies (Taiwan, Huang \& Liu, 2005; Dibrell et al., 2008) show an absence of a direct relationship between innovation and performance and highlight an indirect relationship via the importance given to ICT by the managers. On the other hand, other authors (d'Aral \& Weill, 2007; Kuusisto \& Riepula, 2011; Tambe et al., 2012; Kmieciak et al.,

powerful companv to result in a companv innovating, efficient, reactivates and which evolves/moves surelv and durablv. To improve or control this performance, it is possible to act on 4 principal axes: to be to "horse" enters external space and intern to optimize the productivity, to install indicators of rigorous and specific performance, a collaborative management and to develop a creative know-how of performance.

3The "capacity of innovation of an organization is the capacity to introduce new products on the market or to create new markets by combining a strategic orientation with innovating behaviors and processes (Wang and Ahmed, $2004 ;$ p.305). Sometimes reduced to the capacity to generate innovations of products, it relates to also the capacity to implement all the activities upstream, in particular the innovations of processes (Subramanian, 1996).

\section{DE GRUYTER OPEN}


Tsambou, A. D., \& Fomba Kamga, B. (2017).

Performance perspectives for small and medium enterprises in Cameroon: innovation and ICTs

2012; Raymond et al., 2013) show that the interaction between the capacity of innovation of companies and their ICT capital is positively related to performance. In line with the latter, Ben Aoun et al., (2010) within the framework of the working group of OECD on Luxembourg firms conclude on a positive relationship between the use of ICTs and the propensity to innovate. However, the results of the estimation of a Probit model with random effects correcting for endogeneity of ICT variables also shows that this relationship depends on the intensity of use of ICT and the nature of the innovation considered. Moreover, the Multiple Correspondence Analysis (MCA) model extended to the use of ICT developed by Deltour and Lethiais (2014) on Luxembourg firms confirms the positive bond between certain equipments and the capacities of innovation of firms. The results also show that all investments in ICT do not have equal effects on the increase in the capacity of innovation.

Taking into account this divergence of ideas in developed countries, an in-depth study in developing countries is welcome, not only to evaluate the importance of innovation and ICTs in these countries, but also their joint effect on the performance of SMEs.

\section{Methodology and data}

In order to address the research question - that of evaluating the combined effect of the activities of innovation and ICT on the performance of SMEs, this study brings closer the theory innovation to the performance of companies. The methodological elements presented here include the source of the data, the specification of the model and the variables of the empirical model.

\subsection{Source of data}

The data used come from the General Company Survey (RGE) carried out in 2009 by the National Institute of Statistics (NIS). Although this database is older than the World Bank's Enterprise Surveys, conducted for Cameroon in 2016, it addresses directly our variables of interest. In addition it was done on the whole extent of Cameroonian territory whereas World Bank's database relies only on three cities (Yaoundé, Douala \& Bafoussam). The RGE survey is carried out on 93969 companies and in Cameroon. This survey included $86.5 \%$ of companies of the tertiary sector, $(13.1 \%)$ the secondary industry and only $(0.4 \%)$ of primary companies. The main objective of the survey was to have a better knowledge of the situation of companies in order to set up strategies enabling the authorities, economic operators and other analysts to better play their role. The information contained in this survey relates to the company (age, branch of industry, number of employees, value added), to its manager and his employees (age, sex, level of education, and professional experience), to the business environment (level of corruption, opportunities and competition), to technological innovation, the use of ICT and the stock of production. The survey covered all the national territory by targeting all the economic units found in the field. This study focuses on companies carrying

\section{DE GRUYTER OPEN}

Timisoara Journal of Economics and Business | ISSN: 2286-0991 | www.tjeb.ro Year 2017 | Volume 10 | Issue 1 | Pages: 68-87 
Tsambou, A. D., \& Fomba Kamga, B. (2017).

out their activities in fixed and permanent buildings. The classification used here is that of the National Institute of the Statistics (INS, 2009), which defines micro enterprises in accordance with decrees and laws (law N 0 86/009 of July 5, 1986) of the legal and legislative power. According to this classification, the Charter of the Investments of Cameroon defines the micro enterprise as companies having less than 5 employees and less than 15 million francs CFA of sales turnover; the small businesses are those having between 6 and 20 employees and a sales turnover ranging between 15 million and 500 million francs CFA; the medium-sized companies are those having between 21 and 100 employees and turnover ranging between 500 million and one (01) billion francs CFA. Using this classification we extract 4078 SME from the 8035 surveyed companies. The companies of this sample are those having carried out at least one activity of innovation. Based on the strong representativeness of data in the secondary and tertiary sector, our analyses will focus only on these two sectors.

\subsection{Specification of the econometric model}

The dimension of innovation and ICT analyzed in this study is that on the measurement of the returns of the activities of innovation combined with the use of ICT in terms of productivity. Although many authors have tried to measure the performance of the companies, they do not all use the same measuring instruments. Some (Gauzente, 2011; Adams et al., 2006) use accounting indicators of the company calculated using the operating accounts or balance sheet of the company, and associate it to its economic and financial performance. Here, we find amongst others: the value added, growth of sales turnover (CA), production, the gross operating surplus, the gross operating income and the net profit. Apart from these accounting indicators, other authors (Louizi, 2011; Charreaux, 2004) use financial ratios such as: profitability (the ratio between the profits realised and the turnover), the rotation of capital (the ratio between turnover and the amount invested), the return on the investment (ratio between the profits realised and the amount invested), the returns on assets (the ratio between the net profits and the total assets), the returns on equity (the ratio between the net profits and stockholders equity) and Tobin's Q.

A summary of these indicators makes it possible to evaluate the combined effect of innovation and ICT. However, to estimate the performance, we consider a relationship linking gross margin (or value added) to the inputs $K$, capital and $L$, labour (see for example King \& Park 2004).

$$
V A=\theta \mathrm{f}(\mathrm{K}, \mathrm{L})
$$

\section{DE GRUYTER OPEN}

Timisoara Journal of Economics and Business | ISSN: 2286-0991 | www.tjeb.ro Year 2017 | Volume 10 | Issue 1 | Pages: 68-87 
Tsambou, A. D., \& Fomba Kamga, B. (2017).

Where the factor $\theta$ captures unobservable factors found directly in the production process of the company. By supposing a Cobb-Douglas type ${ }^{4}$ functional form, $\left(V A_{i}=\theta_{i} f\left(K_{i}, L_{i}\right)=\theta_{i} K_{i}^{\beta_{K}} L_{i}^{\beta_{L}}\right)$, we can specify the gross margin per employee in the following way.

$$
(V A / L)_{i}=\theta_{i}\left(\frac{K}{L}\right)_{i}^{\beta_{K}} L_{i}^{\beta_{L}+\beta_{K}-1}
$$

The case of constant returns to scale ( $\beta_{K}+\beta_{L}=1$ ) would make the coefficient of labour to be zero. By integrating the logarithm into this functional form, we have:

$$
\ln (V A / L)_{i}=\ln \theta_{i}+\beta_{K} \ln (K / L)_{i}+\alpha \ln L_{i} \text { with } \alpha=\beta_{K}+\beta_{L}-1
$$

The measure of performance used in this study is the value added per employee. This measure incorporates at least one of the following three aspects: quantity and the arrangement of new products marketed, selling prices of the goods sold, and costs of acquisition of the goods sold. Each one of these aspects can be affected by the characteristics of the company and the quality of the service, by the operating practices of the company, by the capacity of innovation, the use of new information and telecommunications technologies and related commercial practices.

Since the term $\theta_{i}$ captures factors other than the standard factors of production (capital and labor), we make the hypothesis that it depends on the capacity of innovation and use of ICT (Deltour \& Lethiais, 2014), the observable characteristics of the entrepreneur (Paulson et al., 2006) and the characteristics of the company and the market (King \& Park, 2004). In this study, we generalize the assumptions of these authors by assuming that; this term captures the unobservable factors of the classical production process, it depends on the capacity of innovation, the use of ICT tools and the innovation-ITC synergy. Thus, the logarithm of $\theta_{i}$ of company $i$ is:

\footnotetext{
${ }^{4} \mathrm{~A}$ function of production is a mathematical relation established between the produced quantity and the factors of production used, or between the output and the inputs. In neo-classic optics, one incorporates the individual behaviors of the producers starting from their individual functions of production to obtain a function of aggregate output whose function the Douglas one is an
} example.

\section{DE GRUYTER} OPEN
Timisoara Journal of Economics and Business | ISSN: 2286-0991 | www.tjeb.ro Year 2017 | Volume 10 | Issue 1 | Pages: 68-87 
Tsambou, A. D., \& Fomba Kamga, B. (2017).

Performance perspectives for small and medium enterprises in Cameroon: innovation and ICTs

$$
\ln \theta_{i}=\alpha+\gamma C A P_{-} I N N O V_{i}+\lambda C A P_{-} T I C_{i}+\tau \sum C O M B_{i}+\varepsilon_{i}
$$

Where $C A P_{-} I N N O V$ is the variable related to the capacity of innovation, $C A P_{-} T I C_{i}$ the variable related to the capacity in ICT and $C O M B_{i}$ the vector of ICT variables related to the combination of the activities of innovation and the use of ICT. The terms $\varepsilon_{i}$ can be seen as errors of measurement or shocks on the productivity of companies, and are independently and normally distributed with zero mean.

By introducing equation (4) into (3), we obtain a reduced form of the model where the logarithm of productivity per employee is explained in addition to the traditional factors of production (capital and labor), by the contribution of innovations, ICTs and the combination of these two.

$$
L n(V A / L)_{i}=\alpha+\gamma C A P_{-} I N N O V_{i}+\lambda C A P_{-} T I C_{i}+\tau \sum C O M B_{i}+\beta_{K} \ln (K / L)_{i}+\alpha \ln L_{i}+\varepsilon_{i}
$$

The latter equation (5) is estimated by the ordinary least squares method.

\subsection{Choice of variables}

We will describe variables relating to the technological innovation, the use of ICT, the accompaniment of the activities of innovation by ICT, as well as their combination. As regards the variables representing activity of innovation in the SME, the capacity to innovate is measured by investments in R\&D (Huang \& Liu 2005). An alternative approach then consists in estimating the capacity of acquisition of the results of the centers of R\&D that the company could create. Subramanian (1996) highlights the importance of the measure of the capacity of innovation being multidimensional. Among the different dimensions of the capacity of innovation in this study, we have: investment in R\&D experiments, the acquisition of the services of R\&D and the introduction of new goods on the market. Since the quality of the company is measured by the value of the products it markets, R\&D allows the firm to rethink its products in order to ensure its sustainability. It thus plays an essential role in bringing improved products to market and responding to market demands.

Concerning the variables related to the use of ICT by SMEs, they are characterized according to two complementary dimensions following Aral and Weill (2007): the internal ICT assets and computing competences. The ICT assets correspond to the investment in equipments and software in the company. In this study, an approach based on the rate of computerization of the company captured by the rate of access to the computing and the rate of employees knowing how to use the computer is retained. In addition, the use of the internet, intranet

\section{DE GRUYTER OPEN}


Tsambou, A. D., \& Fomba Kamga, B. (2017).

Performance perspectives for small and medium enterprises in Cameroon: innovation and ICTs

and online business practice is necessary for the entire operation of the company. Information and communication technologies (ICTs) encompass all techniques used in information technology, telecommunications or the Internet to produce, transform, store or transmit information. These techniques include both "physical" tools (computers, tablets, smartphones, wired networks, etc.) as well as dematerialized tools (software, wireless connections, e-mail, internet / extranet, etc.).

As for the variables relating to the accompaniment of the activities of innovation by ICT, ICT dedicated to innovation corresponds either to investments in specific tools related to the installation of technological innovations, or to the increased use of the ICT tools available within the framework of the activity of innovation. Moreover, the training of the employees in a company on the use of ICT for the activity of innovation is a significant indicator of the human capital (Abeysekeraa \& Guthrieb, 2004). We approximate our variables of interest by a linear combination of the variables used to represent the data. This combination of variables is used to generate unobservable variables using other variables already defined.

Table 1. Description of variables

\begin{tabular}{|c|c|}
\hline Variables & Description \\
\hline \multicolumn{2}{|c|}{ Dependent variable } \\
\hline VA & Value Added of the year (2009) of investigation in thousands of CFA francs \\
\hline \multicolumn{2}{|c|}{ Standard factors of production } \\
\hline CPT & Investment Capital in thousands of CFA francs \\
\hline TRL & Total staff employed \\
\hline \multicolumn{2}{|c|}{ Variables related to the activities of innovation } \\
\hline CAP_INNOV & Capacity of innovation measured by investments in the activity of innovation \\
\hline TAUX_INNOV & $\begin{array}{l}\text { Rate of innovation per region = a number of companies innovating in the region on the } \\
\text { total number of companies surveyed in the region }\end{array}$ \\
\hline RESUL_R\&D & Percentage of use of $R \& D$ results \\
\hline$R \& D$ & R\&D experiments: 1 = yes, 2 = no \\
\hline SER_R\&D & Acquisition of the services of R\&D: $1=$ yes, $2=$ no \\
\hline NOU_PROD & New products on the market: $1=$ yes, $2=$ no \\
\hline \multicolumn{2}{|c|}{ Variables related to the use of ICT } \\
\hline NOM_ORDI & Numbers of functional computers \\
\hline CAP_TIC & ICT capacity measured by investments in ICT \\
\hline TAUX_TIC & $\begin{array}{l}\text { Utilisation ratio of ICT by region = number of companies using ICT in a region on the total } \\
\text { number of companies surveyed in the region }\end{array}$ \\
\hline UTIL_TIC & Use of ICT: 1 = yes, 2 = no \\
\hline
\end{tabular}

DE GRUYTER OPEN
Timisoara Journal of Economics and Business | ISSN: 2286-0991 | www.tjeb.ro

Year 2017 | Volume 10 | Issue 1 | Pages: 68-87 
Tsambou, A. D., \& Fomba Kamga, B. (2017).

Performance perspectives for small and medium enterprises in Cameroon: innovation and ICTs

\begin{tabular}{cl}
\hline Variables & \multicolumn{1}{c}{ Description } \\
\hline TAUX_ORDI & $\begin{array}{l}\text { Rate of access to computer (TAUX_ORDI) }=\text { number of functional computer / number of } \\
\text { people with knowledge on to use of the computer }\end{array}$ \\
\hline Internet & Internet Connection: $1=$ yes, $2=$ no \\
\hline Intranet & Intranet Connection: $1=$ yes, $2=$ no \\
\hline AF_NET & Practice of business online: $1=$ yes, $2=$ no \\
\hline Variables related to the support of innovation activities by ICT \\
\hline F_TIC & Training related to ICT for activities of innovation: $1=$ yes, $2=$ no \\
\hline LOG_INNOV & Acquisition of software related to technological innovation: $1=$ yes, $2=$ no \\
\hline MA_INNOV & Acquisition of machines related to technological innovations: $1=$ yes, $2=$ no \\
\hline COMB & Combination of ICT Capacity of innovation X utilisation Ratio of ICT \\
\hline Combined variables \\
\hline R\&D_NET & Combination of R\&D and the use of internet connection \\
\hline R\&D_AF_NET & Combination of R\&D and the use of the Intranet for business \\
\hline SERVR\&D & $\begin{array}{l}\text { Combination of the use of the results of the research centers and the use of the intranet } \\
\text { INTRA }\end{array}$ \\
\hline $\begin{array}{l}\text { Log-innov_ma- } \\
\text { innov_nous-pro }\end{array}$ \\
\hline
\end{tabular}

\section{Results}

Innovation and ICT being diffused in many activities and processes of companies, their potential effects are many. In order to clarify these effects, we carry out a statistical and econometric analysis.

\subsection{Analysis of descriptive statistics}

Table 2 presents the statistics of variables related to the innovation and ICT capacity of the firms studied. By the probabilistic theory, the calculation of these statistics allows the enumeration of the observations as well as the frequencies of the variables used. Thus, the use of computers in enterprises has become a common practice, to the point where $90 \%$ of SMEs have at least one computer as their working tool (with an average of 7 computers per SME according to its size). The presence or not of this ICT tool in the company is not always related to the capacity of the personnel to use it. Thus, less than $50 \%$ of employees who master the computer tool have access to the computer at work. It should be recalled that the penetration of the computer in the national territory remains unequal according to the branch of industry, being much more visible in the tertiary sector $(58.24 \%)$ and the secondary

\section{DE GRUYTER OPEN}

Timisoara Journal of Economics and Business | ISSN: 2286-0991 | www.tjeb.ro

Year 2017 | Volume 10 | Issue 1 | Pages: 68-87 
Tsambou, A. D., \& Fomba Kamga, B. (2017).

Performance perspectives for small and medium enterprises in Cameroon: innovation and ICTs

industry $(41.42 \%)$. On the other hand, it is less in the primary sector (0.34\%). This sector is characterized by the low qualification of the personnel in matters of computer knowledge.

Table 2. Descriptive statistics (\%)

\begin{tabular}{|c|c|c|c|c|}
\hline Variables & Description & Secondary industry & Tertiary Sector & Global \\
\hline VA & $\begin{array}{c}\text { Average } \\
\text { Standard deviation }\end{array}$ & $\begin{array}{l}6058749 \\
7.6 \ddot{+}+07\end{array}$ & $\begin{array}{l}6503802 \\
8.0 \grave{+}+07\end{array}$ & $\begin{array}{l}767.5298 \\
7.9 e ́+07\end{array}$ \\
\hline \multicolumn{5}{|c|}{ Standard factors of production } \\
\hline CPT & $\begin{array}{c}\text { Average } \\
\text { Standard deviation }\end{array}$ & $\begin{array}{l}263520.3 \\
1.08 e+07\end{array}$ & $\begin{array}{l}191231.2 \\
1.17 \mathrm{e}+07\end{array}$ & $\begin{array}{c}202129.3 \\
1.1 \ddot{e}+07\end{array}$ \\
\hline TRL & $\begin{array}{c}\text { Average } \\
\text { Standard deviation }\end{array}$ & $\begin{array}{c}2.324519 \\
46.5719\end{array}$ & $\begin{array}{l}1.281761 \\
5.799491\end{array}$ & $\begin{array}{l}1.430092 \\
17.82692\end{array}$ \\
\hline \multicolumn{5}{|c|}{ Variables related to the activities of innovation } \\
\hline CAP_INNOV & $\begin{array}{c}\text { Average } \\
\text { Standard deviation }\end{array}$ & $\begin{array}{l}1712.448 \\
53748.09\end{array}$ & $\begin{array}{l}602.9279 \\
33643.82\end{array}$ & $\begin{array}{l}9176.213 \\
37318.18\end{array}$ \\
\hline RESUL_R\&D & $\begin{array}{l}\text { Yes } \\
\text { No }\end{array}$ & $\begin{array}{l}13.66 \\
86.34\end{array}$ & $\begin{array}{c}9.97 \\
90.03\end{array}$ & $\begin{array}{l}10.59 \\
89.41\end{array}$ \\
\hline R\&D & $\begin{array}{l}\text { Yes } \\
\text { No }\end{array}$ & $\begin{array}{c}4.23 \\
95.77\end{array}$ & $\begin{array}{c}1.87 \\
98.13\end{array}$ & $\begin{array}{c}2.22 \\
97.78\end{array}$ \\
\hline SER_R\&D & $\begin{array}{l}\text { Yes } \\
\text { No }\end{array}$ & $\begin{array}{c}2.29 \\
97.71\end{array}$ & $\begin{array}{c}1.46 \\
98.54\end{array}$ & $\begin{array}{c}1.62 \\
98.38\end{array}$ \\
\hline NOU_PROD & $\begin{array}{l}\text { Yes } \\
\text { No }\end{array}$ & $\begin{array}{c}2.47 \\
97.53\end{array}$ & $\begin{array}{l}1.00 \\
99.00\end{array}$ & $\begin{array}{c}1.21 \\
98.79\end{array}$ \\
\hline \multicolumn{5}{|c|}{ Variables related to the use of ICT } \\
\hline NOM_ORDI & $\begin{array}{c}\text { Average } \\
\text { Standard deviation }\end{array}$ & $\begin{array}{c}84.311 \\
260.999\end{array}$ & $\begin{array}{c}89.6507 \\
273.1931\end{array}$ & $\begin{array}{l}90.027 \\
273.08\end{array}$ \\
\hline CAP_TIC & $\begin{array}{c}\text { Average } \\
\text { Standard deviation }\end{array}$ & $\begin{array}{c}4073.24 \\
91904.59\end{array}$ & $\begin{array}{l}2181.161 \\
68462.45\end{array}$ & 2431.34871825 .2 \\
\hline TAUX_ORDI & $\begin{array}{c}\text { Average } \\
\text { Standard deviation }\end{array}$ & $\begin{array}{l}037675 \\
194717\end{array}$ & $\begin{array}{l}0569804 \\
2.598147\end{array}$ & $\begin{array}{l}0538785 \\
2.395613\end{array}$ \\
\hline UTIL_TIC & $\begin{array}{l}\text { Yes } \\
\text { No }\end{array}$ & $\begin{array}{l}84.02 \\
15.98\end{array}$ & $\begin{array}{l}77.91 \\
22.09\end{array}$ & $\begin{array}{l}78.66 \\
21.34\end{array}$ \\
\hline Internet & $\begin{array}{l}\text { Yes } \\
\text { No }\end{array}$ & $\begin{array}{l}63.86 \\
36.14\end{array}$ & $\begin{array}{l}46.78 \\
53.22\end{array}$ & $\begin{array}{l}49.28 \\
50.72\end{array}$ \\
\hline Intranet & $\begin{array}{l}\text { Yes } \\
\text { No }\end{array}$ & $\begin{array}{l}30.98 \\
69.02\end{array}$ & $\begin{array}{l}21.74 \\
78.26\end{array}$ & $\begin{array}{l}23.22 \\
76.78\end{array}$ \\
\hline AF_NET & $\begin{array}{l}\text { Yes } \\
\text { No }\end{array}$ & $\begin{array}{l}51.97 \\
48.03\end{array}$ & $\begin{array}{l}31.31 \\
68.69\end{array}$ & $\begin{array}{l}34.15 \\
65.85\end{array}$ \\
\hline F_TIC & $\begin{array}{l}\text { Yes } \\
\text { No }\end{array}$ & $\begin{array}{c}7.23 \\
92.77\end{array}$ & $\begin{array}{c}4.26 \\
95.74\end{array}$ & $\begin{array}{c}4.64 \\
95.36\end{array}$ \\
\hline Variables relate & o the support of innc & ovation activities by & & \\
\hline LOG_INNOV & $\begin{array}{l}\text { Yes } \\
\text { No }\end{array}$ & $\begin{array}{c}7.94 \\
92.06\end{array}$ & $\begin{array}{c}5.53 \\
94.47\end{array}$ & $\begin{array}{c}5.82 \\
94.18\end{array}$ \\
\hline
\end{tabular}

DE GRUYTER OPEN
Timisoara Journal of Economics and Business | ISSN: 2286-0991 | www.tjeb.ro Year 2017 | Volume 10 | Issue 1 | Pages: 68-87 
Tsambou, A. D., \& Fomba Kamga, B. (2017).

Performance perspectives for small and medium enterprises in Cameroon: innovation and ICTs

\begin{tabular}{ccccc}
\hline Variables & Description & Secondary industry & Tertiary Sector & Global \\
\hline MA_INNOV & Yes & 9.70 & 7.83 & 8.14 \\
& No & 90.30 & 92.17 & 91.86 \\
\hline \multirow{2}{*}{ COMB } & Average & 5785.687 & 2784.088 & 3198.878 \\
& Standard deviation & 132873.2 & 90442.79 & 97400.98 \\
\hline
\end{tabular}

Generally, the anchoring of ICT is weak in SMEs. Less than 2 thirds of SMEs are connected to the internet (49.28\%) and a weaker proportion (less than one-fifth) has an intranet network (23.22\%) within the company. A study of the Ministry of Communications carried out in 2005 locates at $12 \%$ the proportion of companies connected to the internet. Thus, four years later (INS, 2009) there has been a clear improvement which is explained by the strong competition observed in the sector of telecommunications as well as the considerable lowering of the costs of supports such as the computer and the telephone. In addition, apart from the tertiary sector (banks for example) which have in their majority an intranet network, the other sectors experience an embryonic development of this tool. Concerning the use of the internet for business operations (E-commerce), the phenomenon touches only nearly a quarter (34.15\%) of the SMEs as a whole. It is much more significant in the companies of the tertiary sector (31.31\%) and the secondary industry (51.97\%). This low use of the internet is partly due to the functioning of the market of internet connection. Thus, two years after the report made by the Ministry of Telecommunications in 2007 (INS, 2009), the underutilisation of the possibilities offered by internet remains a major concern. It is noted in a general manner that the indicators of ICT identified above increase in a systematic manner with the size of the companies, the larger the companies, the higher these indicators are.

As a whole, only $10.59 \%$ of SMEs declare using the results of research centers. The primary sector (agriculture for example) which usually witnesses a rather high dissemination of the results of research centers is the sector where the results emanating from these centers are used. As regards technological innovation, very few companies devote an investment to it. The acquisition of machines and innovating equipment $(8.14 \%)$, of software related to the dependent innovations (5.82\%) and ICT training for an activity on innovation (4.64\%) are the three fields where they center their development (table 2).

Concerning the environment of the businesses, only $2.53 \%$ of the heads of companies have a good opinion, $16.11 \%$ a rather good opinion, $36.46 \%$ a bad opinion, while $44.90 \%$ are indifferent or undecided. In spite of the efforts made by the government and the Interemployers Group of Cameroon (GICAM) for the improvement of the environment of business, the majority of heads of companies are pessimistic and consequently anxious for the future of their business. Generally the most optimistic heads of the companies are in the primary sector (agriculture, livestock farming) and to a lesser extent in the tertiary sector (banking and insurance). On the other hand the latter are more pessimistic in the secondary industry (manufacturing).

\section{DE GRUYTER OPEN}

Timisoara Journal of Economics and Business | ISSN: 2286-0991 | www.tjeb.ro Year 2017 | Volume 10 | Issue 1 | Pages: 68-87 
Tsambou, A. D., \& Fomba Kamga, B. (2017).

Performance perspectives for small and medium enterprises in Cameroon: innovation and ICTs

\subsection{Analysis of econometric results}

Taking into account the relevance of the variables, the results of our first regression are presented in table 3. According to this table, the capacity of innovation or the capacity of ICT do not have the same result as when they are combined.

Table 3. Econometric result of the combination between innovation and ICT

\begin{tabular}{|c|c|c|c|}
\hline \multirow[t]{2}{*}{ Variables } & Secondary industry & Tertiary Sector & Together \\
\hline & Coef. & Coef. & Coef. \\
\hline \multicolumn{4}{|c|}{ Traditional factors of production } \\
\hline Log_CPT & $\begin{array}{c}5290 * * * \\
(.0634)\end{array}$ & $\begin{array}{c}4280 * * * \\
(.0267)\end{array}$ & $\begin{array}{c}4670 * * * \\
(.0250)\end{array}$ \\
\hline Log_TRL & $\begin{array}{c}3074 * * * \\
(.0682)\end{array}$ & $\begin{array}{l}1343 * * \\
(.0651)\end{array}$ & $\begin{array}{c}2018 * * * \\
(.0473)\end{array}$ \\
\hline \multicolumn{4}{|c|}{ Variables related to innovation activities and the use of ICT } \\
\hline LogCAP_INNOV & $\begin{array}{l}-.3087 \\
(.2349)\end{array}$ & $\begin{array}{l}-.1403 \\
(.1790)\end{array}$ & $\begin{array}{l}-.1637 \\
(.1498)\end{array}$ \\
\hline TAUX_INNOV & $\begin{array}{c}22.85 \\
(17.78)\end{array}$ & $\begin{array}{c}16.94 * * * \\
(6.369)\end{array}$ & $\begin{array}{c}15.179 * * \\
(5.978)\end{array}$ \\
\hline logCAP_TIC & $\begin{array}{c}-3.019 * * * \\
(1.008)\end{array}$ & $\begin{array}{l}-.8924 \\
(.5682)\end{array}$ & $\begin{array}{c}-1.113 * * \\
(.4946)\end{array}$ \\
\hline TAUX_TIC & $\begin{array}{c}12.34 \\
(8.533)\end{array}$ & $\begin{array}{l}5.044 * * \\
(2.448)\end{array}$ & $\begin{array}{l}7.219 * * * \\
(2.461)\end{array}$ \\
\hline \multicolumn{4}{|l|}{ Combined variables } \\
\hline COMB & $\begin{array}{c}7269 * * * \\
(.1818)\end{array}$ & $\begin{array}{l}2365 * * \\
(.1169)\end{array}$ & $\begin{array}{c}3136 * * * \\
(.0983)\end{array}$ \\
\hline RD_NET & $\begin{array}{l}3.106 * * * \\
(1.070)\end{array}$ & $\begin{array}{l}2.245 * * * \\
(.5104)\end{array}$ & $\begin{array}{l}2.445 * * * \\
(.4654)\end{array}$ \\
\hline RD_AF_NET & $\begin{array}{c}1.224 \\
(1.5138)\end{array}$ & $\begin{array}{c}-3.310 * * \\
(1.349)\end{array}$ & $\begin{array}{r}-2.672 * * \\
(1.0476)\end{array}$ \\
\hline SERVR\&D_INTRA & $\begin{array}{l}-1.564 \\
(1.747)\end{array}$ & $\begin{array}{l}2.160 * \\
(1.1268)\end{array}$ & $\begin{array}{l}1.615 * \\
(.9178)\end{array}$ \\
\hline $\begin{array}{l}\text { Log-INNOV_MA- } \\
\text { INNOV_NOU-PRO }\end{array}$ & $\begin{array}{c}1.093 \\
(1.858)\end{array}$ & $\begin{array}{c}3.796 * * \\
(1.683)\end{array}$ & $\begin{array}{c}3.477 * * \\
(1.354)\end{array}$ \\
\hline Constant & $\begin{array}{l}3.750 * * * \\
(.8244)\end{array}$ & $\begin{array}{l}3.862 * * * \\
(.3085)\end{array}$ & $\begin{array}{l}3.577 * * * \\
(.29124)\end{array}$ \\
\hline $\mathrm{F}$ & 25.29 & 33.59 & 53.73 \\
\hline Prob $>\mathrm{F}$ & 0.0000 & 0.0000 & 0.0000 \\
\hline R-squared & 0.4392 & 0.2113 & 0.2632 \\
\hline Number of obs & 396 & 2180 & 2613 \\
\hline
\end{tabular}

Note: $* * *(1 \%) * *(5 \%) *(10 \%)$; standard deviations are in brackets

As a whole, the coefficient $(0.2018)$ attached to the factor labour is positive and significant at the $1 \%$ level. This means that a $10 \%$ increase in the number of workers is associated with 
Tsambou, A. D., \& Fomba Kamga, B. (2017).

an increase of $20.18 \%$ of the gross margin. This increase is also associated to a rise of $13.43 \%$ and $30.74 \%$ in the value added in the tertiary and secondary sector respectively. In the same manner, the coefficient $(0.467)$ related to investment in capital is positive and significant at the $1 \%$ level. This means that an increase of $10 \%$ in investments is associated with an increase of $46.7 \%$ in the gross margin per worker. This variation of $10 \%$ would have an incremental effect of $42.8 \%$ and $52.9 \%$ on the gross margin by worker in the tertiary and secondary sector respectively. The sum of the coefficients of the two traditional factors of production, investment in capital (CPT) and the total number of workers (TRL) be it numerically or significantly as a whole or in the various sectors of activity, is around 0.6. This sum of the classical factors of production is less than unity, a proof that a large part of the gross margin of the firm is explained by other factors such as: capacity of innovation, the use of ICT and the combined effect between innovation and ICT. This econometric model explains the performance of firms according to the capacity of innovation, ICT and their combination. The coefficient of determination $\mathrm{R}^{2}=0.2632(0.4392$ for the secondary sector and 0.2113 for the tertiary sector, respectively) reveals that $26.32 \%$ of firms' performance (44\% for secondary and $21 \%$ for firms in the tertiary sector) is explained by the explanatory variables.

\section{Discussion}

\subsection{Separate effect of innovation and ICT}

According to the results of Table 3, the innovation capacity taken alone has a non-significant and negative effect on the performance of the SMEs as a whole, as well as at the level of the sectors of activity. This negative effect can be explained by the difficulties in terms of return on investment for this activity in SMEs. In fact, the implementation of innovations has a significant cost, but the benefits from this activity remain dubious at the commercial level. In the same manner, the cost of computerization is high whereas technologies tend to quickly become obsolete and they hardly make it possible for a firm to distinguish itself from the others. These results are in line with those of Dibrell et al., (2008) which concludes on the non-significant and negative direct effect of the capacity of innovation on performance. In a context made up of mostly SMEs, this result can be related to the absence of internal competences which halt the activity of innovation or its success on the market. This analysis joins that of Hadjimanolis (2000) on the case studies in SMEs which confirm the role of the characteristics of owner/manager in explaining the capacity of innovation (a potential source of benefit).

Contrary to the positive effect of the existing literature (Dibrell et al., 2008; Huang \& Liu, 2005), the effect of the capacity of ICT on the performance of SMEs is negative and significant globally and in the secondary industry; especially since the use of ICT requires new individual and collective competences to the point where innovating firms are tempted to call upon the external labour market to employ these new competences. This is not necessarily efficient for

\section{DE GRUYTER OPEN}

Timisoara Journal of Economics and Business | ISSN: 2286-0991 | www.tjeb.ro Year 2017 | Volume 10 | Issue 1 | Pages: 68-87 
Tsambou, A. D., \& Fomba Kamga, B. (2017).

small companies. This contradictory result is explained by the various measures used to determine the ICT capacity. Whereas Dibrell et al. (2008) measure the capacity of ICT by the total budget allocated to ICT, we have, given the quality of data, used the approach of Aral and Weill (2007) and made the choice to consider on the one hand the resources of computerization and on the other hand the use of ICT tools in the practice of business. Thus, the activity of installation of innovating products can be based on specific investments in ICT, and can be also be based on the ICT tools already present in the company which will be mobilized in a more intense way. Also, the majorities of SMEs in the Cameroonian context are managed by the owners, and use family labour. This makes the relationship with computing not obvious for these organizations of small size. For this reason, these SMEs very often develop a feeling of personification of the activities and impotence vis-a-vis ICTs, given the manner of implementing the ICT concerned, their complexity, their number or competences of the associated people.

Innovation having become the "burning obligation" of political rhetoric, its regional level as well as the regional level of use of ICT affects the productivity of the firms significantly. This positive relationship significant at $5 \%$ level is explained by the potential of innovation of a region. This is given by the sum of the capacities of innovation of the economic agents and the set of externalities resulting from the activities of innovation. Regional innovation, which strongly depends on the capacity of individual initiative and the degree of interpersonal confidence in the economic relationships, is to a certain degree a non rival good in the sense that it can benefit an infinite number of agents (at least when it is not protected) without any being deprived. Because of its characteristics, the latter is at the origin of knowledge externalities between economic agents.

\subsection{Combined effects of innovation and ICT}

The effect of the combination of the capacity of innovation and the capacity of ICT are positive and significant at the $1 \%$ level in all sectors of activity whereas the individual effects of these indicators remain significant and negative in these sectors. This strong significance is explained by the fact that ICTs have advantages like effectiveness, efficiency, assistance in decision-making, intensification of communication or mobility, which is not without effect on the accomplished tasks. Because of this, the effect of the innovation on performance could not be right without being accompanied by ICT. Moreover, the degree of rooting of the use of ICT in the company allows the managers and employees to accelerate the process of innovation, thereby improving the performance of firms in term of reduction of costs and rationalisation of processes. In the same manner, innovative SMEs benefits from ICT in matters of social dialogue. This means that the establishment of the intranet for example would accompany commercial innovations insofar as electronic messages can replace the notice boards. The description of an effect of synergy between ICTs and innovation is in fact in line with the results of Huang and Liu (2005) on large companies. These results are

\section{DE GRUYTER OPEN}

Timisoara Journal of Economics and Business | ISSN: 2286-0991 | www.tjeb.ro Year 2017 | Volume 10 | Issue 1 | Pages: 68-87 
Tsambou, A. D., \& Fomba Kamga, B. (2017).

different from those of Raymond et al., (2013) on a sample of Canadian SMEs. The use of ICT tools specifically mobilized within the framework of innovations supports the operational activities. If software dedicated to the management of innovation can exist, the numerical supports of the innovation are ICT tools. In this line, Dibrell et al., (2008) show that the capacity of innovation has an effect on performance only through an increase in ICT resources, the direct effect being non-significant.

According to the results of table 5 , several combinations of variables present convincing effects on the performance of companies. The combination of R\&D and the use of internet connection have a positive effect on the performance of SMEs. The coefficient of this combination significantly affects profits at the $1 \%$ level, whatever the branch of industry. This means that an intensification of experimental research combined with an improvement and a $1 \%$ increase in the capacity of use of internet connection is associated with an increase of 2,44 points in the value added as a whole and respectively 2,24 and 3,1 points in the margin of companies of the tertiary and secondary sector. This positive and highly significant value shows that ICT has a significant effect on R\&D activities, both on the conditions of functioning of operations and the teams of research and on the management of these activities. The fluidity of the internet connection leads to the transformation of the activities of research, facilitating certain operations through the integration of automated routines, widening the field of accessible information.

The combination of R\&D and the use of the intranet for business has a significant effect at the $10 \%$ on gross margin of firms. The coefficient of this combination positively influences this margin globally and in the tertiary sector. This means that the intensification of experimental research combined with an increase in the capacity of use of the intranet of $1 \%$ is associated with an increase in 1,61 points of the value added the global level and 2,16 points in the tertiary sector. This positive significance in the tertiary sector is explained by the fact that the intranet makes it possible to develop an inter-organisational co-operation and a spatial proximity, modifying the intra-organisational functiong and the effects of interdependence between space and organisational proximity. This analysis is in line with that of Madeuf et al., (2005) in the Belgian companies, showing that the use of ICT tools for $R \& D$ makes it possible to develop access to information internal or external to the company, to transform and accelerate co-operation between researchers, teams and services.

The combination of the use of the results of research centers and the use of the intranet for business positively impacts the performance of SMEs. The coefficient of this combination significantly affects the value added at the $5 \%$ level globally and the tertiary sector. This means that an increase in the level of use of the results of research centers combined with an increase in the capacity of use of the intranet of $1 \%$ is associated with an increase of 3,47 points in the margin of the company at the global level and 3,79 points in the tertiary sector. This positive significance is explained by the fact that the intranet makes it possible to have

\section{DE GRUYTER OPEN}

Timisoara Journal of Economics and Business | ISSN: 2286-0991 | www.tjeb.ro Year 2017 | Volume 10 | Issue 1 | Pages: 68-87 
Tsambou, A. D., \& Fomba Kamga, B. (2017).

a centralized and coherent access to information of research centers. Much more than a simple data-processing tool, the intranet reflects the policy of "knowledge management" of the research centers. The treatment and diffusion of information, mode of division of knowledge, computer governance, make it possible to reduce distance and facilitate exchange. Thus, the combination of the use of the intranet and the use of research results makes it possible to make more efficient the dissemination and use the results of research which contributes to the improvement of performance.

\section{Conclusion}

Engaging into innovation activities is an essential feature of both large and small companies in an environment characterized by a competition. This study has as objective of to evaluate the effect of the capacity of innovation and ICT abilities on the performance of SMEs. To attain this objective, we use a multiple regression model applied to the data of the General Census of Enterprises. The results from this regression are analyzed in two stages.

The statistical analysis shows that the anchoring of ICT is low in SMEs. Only $51.79 \%$ of SMEs have at least a computer as working tool. In the same manner, less than a-third of SMEs are connected to the internet (35.9\%) and a smaller proportion has an intranet network (18.39\%) within the company. Only about a quarter (25.99\%) of SMEs in general, use the internet for business operations (e-commerce). This low use of the internet is related to the operation of the market of internet connection: low speed of connection, high cost of connection, very limited internet offers, etc. Whereas the majority of African countries already migrated to $4 \mathrm{G}$ connection, Cameroon still has difficulties of being able to connect to $3 \mathrm{G}$ completely, although the operators of telecommunication declare having a $4 \mathrm{G}$ connection. This state of the environment slows down the development of electronic commerce. We also find that generally, the indicators of ICT indicated above increase in a systematic manner with the size of the companies. Given the considerable means available to large companies, they can substantially benefit from investment in ICT. SMEs thus need to grow and expand in order to witness returns on investment in ICT.

From our econometric analysis, we find that: by taking into account the low level of the activities of innovation in the global set of SMEs of our sample, we find a non-significant negative effect of the capacity of innovation and ICT taken individually on the performance of SMEs. However, ICT and innovation give rise to a positive and significant relationship with performance. This result shows the need for these companies to accompany their innovation strategies by investments in ICT or a reinforcement of the use of information technologies already present. These results are in line with those of Dibrell et al., (2008) and of Raymond et al., (2013) on Canadian SMEs. If ICTs offer benefits such as efficiency, decision-making support and increased communication, the effect of innovation on performance can not be right without being accompanied by TIC.

\section{DE GRUYTER OPEN}

Timisoara Journal of Economics and Business | ISSN: 2286-0991 | www.tjeb.ro Year 2017 | Volume 10 | Issue 1 | Pages: 68-87 
Tsambou, A. D., \& Fomba Kamga, B. (2017).

Performance perspectives for small and medium enterprises in Cameroon: innovation and ICTs

The role of ICT in innovation is however more significant and the degree of rooting of the use of ICT in SMEs makes it possible to accelerate the process of innovation thereby improving the performance of companies in terms of the reduction of costs and rationalisation of processes. For a new product to be easily marketable, an SME can through the internet: launch offers and publicity, develop various activities such as online trade and exchange with customers or even find new partnerships. ICT initially bring a great change in mentalities and in the manner of processing data within an SME. They also take part in the dematerialisation and the creation of value added. Also, ICTs improve the level of decision-making and facilitate interaction and collaboration between employees and managers. Finally, ICTs accompany the setting-up and realisation of innovations and thereby improve the performance of SMEs.

\section{References}

Abeysekeraa, A., \& Guthrieb, J. (2004). Human capital reporting in a developing nation. The British Accounting Review, 36, 251-268.

Adams, R., Bessant, J., \& Phelps, R. (2006). Innovation management measurement: a review. International Journal of Management Reviews, 8(1), 21.

Admassu, T. (2009). Quelles perspectives de financement pour les PME en Afrique? La revue de PROPARCO.

Aral, S., \& Weill, P. (2007). It Assets, Organizational Capabilities, and Firm Performance: How Resource Allocations and Organizational Differences Explain Performance Variation. Organization Science, 18(5), 763-790.

Ben, Aoun, L., Dubrocard, A., \& Tudor, H. (2010). TIC, innovation et effets perçus dans les entreprises luxembourgeoises. Economie et Statistiques Working papers du STATEC et Observatoire de la Compétitivité.

Mensah, F. B., \& Acquah, I. S. K. (2015). The Effect of Innovation Types on the Performance of Small and Medium Sized enterprises in the Sekondi: Takoradi Metropolis. Archives of Business Research, 3(3), 77-98.

Charreaux, G. (2004). Les théories de la gouvernance : de la gouvernance des entreprises à la gouvernance des systèmes nationaux, Cahier du FARGO n 1040101.

Crépon, B., Duguet, E., \& Mairesse, J. (2000). Mesurer le rendement de l'innovation. Économie et Statistique, 334.

Deltour, F., \& Lethiais, V. (2014). Innovation et performance des PME : une approche par la contribution des technologies de l'information. Association Internationale de Management Stratégique (AIMS), XXIII Conférence Internationale de Management Stratégique.

Dibrell, C., Davis P., \& Craig, J. (2008) Fueling Innovation through Information Technology in SMEs. Journal of Small Business Management, 46(2), 203-218.

Şipoş, G. L., \& lonescu, A. (2015). Stimulating creativity methods and innovative performance in European countries. Timisoara Journal of Economics and Business, 8(1), 163-182. Retrieved from http://www.tjeb.ro/index.php/tjeb/article/view/TJEB8-1_163to182. DOI: $10.1515 /$ tjeb-2015-0013

Gauzente, C. (2011). Mesurer la performance des entreprises en l'absence d'indicateurs objectifs : quelle validité? Analyse de la pertinence de certains indicateurs. Finance Contrôle Stratégie 3(2), 145-65.

DE GRUYTER OPEN 
Tsambou, A. D., \& Fomba Kamga, B. (2017).

Performance perspectives for small and medium enterprises in Cameroon: innovation and ICTs

Greenan, N., \& Mairesse, J. (2006). Réorganisations, changements du travail et renouvellement des compétences. Revue Économique, 57(4).

Hajjem, O, Garrouste, P., \& Ayadi, M. (2015). Effets des innovations technologiques et organisationnelles sur la productivité: Une extension du modèle CDM. Revue d'économie industrielle, 151, 101. ProQuest Central.

Hadjimanolis, A. (2000). A Resource-based View of Innovativeness in Small Firms. Technology Analysis \& Strategic Management, 12(2), 263-281.

Huang; C.J., \& Liu, C.J. (2005). Exploration for the Relationship between Innovation, IT and Performance. Journal of Intellectual Capital, 6(2), 237-252.

INS (2009). Rapport final du recensement général des entreprises au Cameroun.

Jansen, J., Van Den Bosch, F., \& Volberda, H. (2006). Exploratory Innovation, Exploitative Innovation, and Performance: Effects of Organizational Antecedents and Environmental Moderators. Management Science, 52(11), 1661-1674.

King, R.P., Park, \& Timothy, A. (2004). Modeling Productivity in Supermarket Operations. Journal of Food Distribution Research, 35 (2), 42-55.

Kmieciak, R., Michna, A., \& Meczynska, A. (2012). Innovativeness, empowerment and IT capability: evidence from SMEs. Industrial Management \& Data Systems, 112 (5), 707-728.

Kuusisto, A., \& Riepula, M. (2011). Customer interaction in service innovation: seldom intensive but often decisive. Case studies in three business service sectors. International Journal of Technology Management 55(1/2), 171-186.

Liang, T.P., You, J.J., \& Liu, C.C. (2010). A resource-based perspective on information technology and firm performance: a meta analysis, Industrial Management \& Data Systems, 110(8), 1138-1158.

Louizi, A. (2011). Les déterminants d'une Bonne Gouvernance et la performance des entreprises Françaises : Études empiriques. Université Jean Moulin Lyon 3, Université de Sfax, thèse de doctorat en Sciences de gestion sous la direction de ROTH F.

Mairesse, J., Cette G., \& Kocoglu, Y. (2002). La mesure de l'investissement en technologies de l'information et de la communication: quelques considérations méthodologiques. Économie et Statistique, $\mathrm{n}^{\circ} 339-340$, p. 73-91.

Ndesaulwa, A.P. (2016). L'impact de l'innovation sur la performance des petites et moyennes entreprises (PME) en Tanzanie: une revue des preuves empiriques. Journal of Business and Management Sciences, 4(1), 1-6.

Paulson, A.L., Townsend, R.M., \& Karaivanov, A. (2006). Distinguishing Limited Liability from Moral Hazard in a Model of Entrepreneurship. Journal of Political Economy, 114(1), 100-144.

Pavlou, P., \& Sawy, O. (2006). From IT leveraging competence to competitive advantage in turbulent environments: the case of new product development. Information Systems Research, 17(3), 198-227.

OCDE (2007). Travaux de synthèse sur le financement des PME et des entrepreneurs, Paris.

OCDE (2005a). Principe directeurs pour le recueil et l'interprétation des données sur l'innovation. $3^{\mathrm{e}}$ édition.

OCDE (2005b). Oslo Manual, Guidelines for collecting and interpreting innovation data. Paris, OCDE and Eurostat.

Ondel'ansek, K. (2010). Les contraintes de financement des PME en Afrique: le rôle des registres de crédit, thèse de Doctorat, HEC Montreal.

DE GRUYTER OPEN 
Tsambou, A. D., \& Fomba Kamga, B. (2017).

Performance perspectives for small and medium enterprises in Cameroon: innovation and ICTs

Quiles J. (1997). Schumpeter et l'évolution économique : circuit, entrepreneur, capitalisme. Paris : Nathan.

Raymond, L., Bergeron, F., \& Croteau A.M. (2013). Innovation Capability and Performance of Manufacturing SMEs: The Paradoxical Effect of it Integration. Journal of Organizational Computing and Electronic Commerce, 23(3), 249-272.

Raymond, L., \& St-Pierre, J. (2010). R\&D as a determinant of innovation manufacturing SMEs an attempt at empirical clarification. Technovation, 30(3), 48-56.

Rukevwe, J. O. (2015). Effect of Innovation on the Performance of SMEs Organizations in Nigeria, 5(3), 90-95.

Schumpeter, J. (1942). Capitalisme, socialisme et démocratie. Ed française Payot 1990.

Solow, R. (1987). We'd Better Watch Out. New York Times Book Review, 12 juillet.

St-Pierre, J., \& Mathieu, C. (2004). Innovation de produits et performance: une étude exploratoire de la situation des PME canadiennes, $7^{\text {ème }}$ Congrès International Francophone en Entrepreneuriat et PME, Association Internationale de Recherche en Entrepreneuriat et PME (CIFEPME), 27, 28 et 29 Octobre 2004, Montpellier. www.airepme.org

St-Pierre, J., Audet,J., \& Mathieu,C. (2003). Les nouveaux modèles d'affaires des PME manufacturières: une etude exploratoire, Rapport de recherché. Institut de recherché sur les PME. http://www.uqtr.ca/inrpme/pdf/Rapport_final_janvier2003.pdf

Subramanian, A. (1996). Innovativeness: Redefining the Concept. Journal of Engineering and Technology Management, 13(3/4), 223-243.

Tambe, P., Hitt, L., \& Brynjolfsson, E. (2012). The Extroverted Firm: How External Information Practices Affect Innovation and Productivity. Management Science, 58(5), 843-859.

Tidd, J., \& Driver, C. (2000). Technological and market competencies and financial performance. In J. Tidd (ed.) From Knowledge Management to Strategic Competence. 